\title{
Performance of wood and wood-based materials regarding fungal decay
}

\author{
Michiel Vanpachtenbeke ${ }^{1,2, *}$, Jan Van den Bulcke ${ }^{2}$, Joris Van Acker ${ }^{2}$, and Staf Roels ${ }^{1}$ \\ ${ }^{1}$ KU Leuven, Department of Civil Engineering, Building Physics Section, Kasteelpark Arenberg 40 - box 2447, BE-3001 Heverlee, \\ Belgium \\ ${ }^{2}$ UGent, Department of Environment, Laboratory of Wood Technology (UGent-Woodlab), Coupure Links 653, BE-9000 Gent, Belgium
}

\begin{abstract}
Due to the increasingly stringent energy efficiency requirements, timber frame houses are becoming more and more popular across Europe. Depending on the circumstances, timber frame walls might be exposed to high relative humidity or condensation conditions, leading to a risk of fungal degradation. In order to assess the durability of a timber frame construction in a reliable way, a clear view on the potential risk of fungal growth is essential. Various experiments are reported in literature to define the minimal moisture threshold for fungal decay, yet all very different in set-up and hence leading to contradictory conclusions. Therefore, the present paper aims at a contribution to a better understanding of the influence of moisture conditions on the onset and progress of wood decay in timber frame walls. Based on the information that is still lacking in international literature, a new test methodology has been elaborated within this work and is reported in this paper.
\end{abstract}

\section{Introduction}

To meet the increasingly stringent energy efficiency requirements, the market share of timber frame houses is steadily growing across Europe. Timber frame constructions are highly suitable for low energy or Passive houses, and, moreover, wood is a biological and carbon neutral material. A major disadvantage of timber frame constructions, however, is its susceptibility to fungal growth, especially with the growing demand and increasing tendency to use untreated wood $[1,2]$. Recently, the leaky building crisis in New Zealand [3] and British Columbia (B.C.), Canada [4] showed the importance of weather tightness for timber frame buildings. In these buildings, built between 1980 and 2005 , rain water was able to penetrate the building envelope or cladding and became trapped inside the wall, which led to severe wood decay. Next to weather tightness, also airtightness is of great importance for a durable building envelope. Achieving the severe airtightness requirements for timber frame building components is, however, challenging and labourintensive, given the complexity of the structure $[5,6]$. As a consequence, possible exfiltration of humid indoor air may result in interstitial condensation at the colder outer parts of the building component. Finally, depending on the region in which the timber frame construction is built, the circumstances (e.g. composition of the wall, indoor and outdoor climate conditions, etc.) are different and, consequently, a different hygrothermal behaviour can be expected. This makes that timber frame walls might be exposed to high relative humidity or condensation conditions, leading to a risk of mould growth and wood decay. This might severely affect the durability of the construction. Since wood decay fungi consume significant amounts of cell wall material, they might cause problems regarding the structural integrity of the building. In addition, both mould and wood decay fungi in buildings can be a risk for the health of the residents $[7,8]$.

In order to evaluate the durability of a timber frame construction in relation to its hygrothermal performance, a clear view on the onset and progress of fungal growth is essential. In this paper, the focus is on wood decay only. Various laboratory experiments are reported in literature to define the minimal moisture threshold for fungal decay (a.o. [9-13]). In these tests, it is specifically investigated whether fungal decay is possible below 'fibre saturation point'. Since wood is a hygroscopic material, water vapour from the surrounding atmosphere is adsorbed as bound water in the cell walls. In the high RH-range, cell walls are fully saturated and from then on, extra moisture will be absorbed as liquid water in the cell lumen. This point is called the 'fibre saturation point' (FSP). For most wood species, the FSP is situated between $22-30 \%$ moisture content. The conducted experiments reported in literature, however, are all very different in set-up, leading to contradictory conclusions. Generally, in experiments which provided a moisture and nutrition source to the fungus, wood decay (well) below FSP was observed. In contrast, in experiments without an external moisture and nutrition source, the MC threshold was above FSP. All these tests, however, benefitted from inoculation and sterile conditions. In

\footnotetext{
* Corresponding author: michiel.vanpachtenbeke@kuleuven.be
} 
reality, fungal spores first need to settle onto the wood before germination and growth can occur.

Up to now, no tests on the onset of wood decay for conditions occurring in a timber frame wall have been performed. Therefore, the present paper aims at a contribution to a better understanding of the influence of moisture conditions on the onset and progress of fungal decay in timber frame walls. The paper discusses the results of experiments conducted with a newly developed test unit. In these tests, a distinction is made between tests with and without a liquid water source. In practice, built-in moisture, water leakages or condensation can be an essential water source for a fungus to develop, survive and grow.

\section{Experimental set-up}

An updated Fungal Control Unit [14] has been designed and elaborated at Woodlab-UGent. The Fungal Control Unit (FCU) serves as a set-up to investigate the onset and progress of fungal decay in small scale timber frame wall units/elements. The onset and progress of wood decay is studied in a controlled environment, with focus on the importance of the FSP. Tests executed in this unit do not benefit from inoculation and sterile conditions, and hence represent more realistic conditions ocurring in timber frame walls.

The Fungal Control Unit (FCU), as depicted in Figure 1a, consists of three modules, with an inner width and height of $1 \mathrm{~m}$ but variable length, which can be attached to and separated from each other. The structural frame of all modules is made from the highly durable tropical wood species Bilinga (Nauclea diderrichii). The modules are insulated with $14 \mathrm{~cm}$ of Polyisocyanurate (PIR) and finished with epoxy coated plywood at the inand outside. Figure 2 presents a schematic overview of the FCU. In a first module, referred to as module A, a frame is provided in which test samples can be mounted. Samples of different dimensions and wood species or wood-based products can be tested. This module is at one side attached to module B. As shown in Figure 1b and depicted in Figure 2, in this module a channel strip heater $^{\mathrm{a}}$ as heat source and a humidifier ${ }^{\mathrm{b}}$ are installed behind a separation wall to regulate the climatic conditions inside the FCU. Three little fans ${ }^{\mathrm{c}}$ in front of a fine wire mesh provide a quasi-laminar air flow across the test samples. A probe is mounted in front of the test samples to continuously monitor the temperature and relative humidity of the air flow. The probe, heat source and humidifier are connected to a PID controller, which ensures a constant climate during the test period. Finally, the third module, module $\mathrm{C}$, is attached to the other side of module A. It is initially designed to close the FCU from the outside in order to maintain constant climatic conditions inside the FCU, but will be extended in following tests (see further).

${ }^{\text {a }} \mathrm{CSH} 3$, Omega

(https://www.omega.nl/pptst/CSH3_SERIES.html)

b BURG BH-850E

c 622L Axial Fan, EBM PAPST

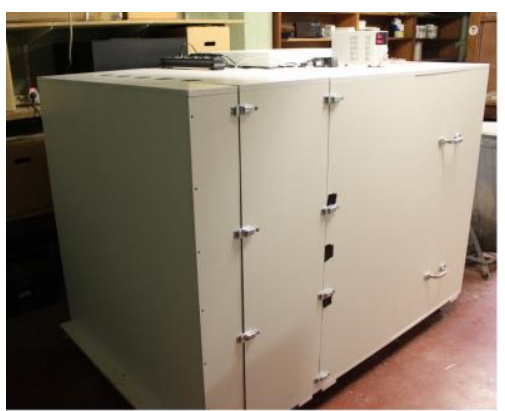

(a)

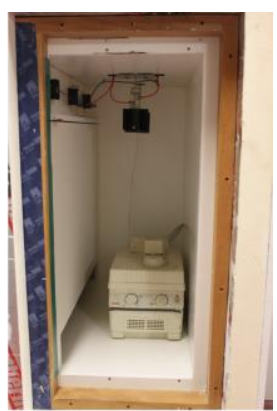

(b)
Figure 1: a) The fungal control unit (FCU) serves as a test room in which wood or wood-based samples are exposed to a controlled environment; b) A heat source and humidifier behind a separation wall in module B are controlled by a PID controller to regulate the climatic conditions inside the FCU.

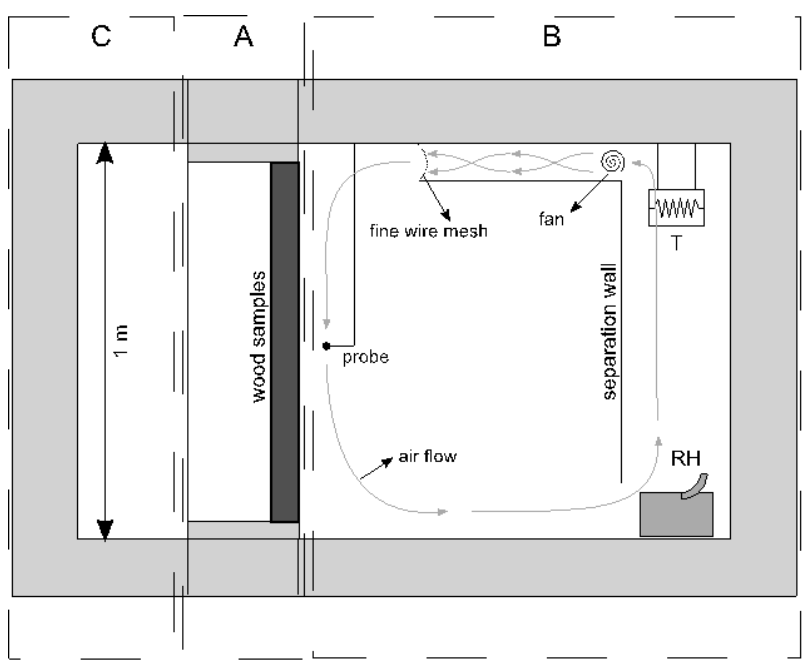

Figure 2: Schematic overview of the FCU, consisting of three modules.

\section{FCU - test 1}

In a first FCU test, the onset of wood decay is investigated in case no liquid water source is available. The considered materials are Scots pine (Pinus sylvestris L.), Norway spruce (Picea abies Karst.) and OSB. In addition to these materials, also a bituminous impregnated wood fibre board ${ }^{\mathrm{d}}$ and a wood fibre cement board $^{\mathrm{e}}$, which are typically used as exterior sheathing in timber frame walls, are investigated ('open WB' and 'tight WB' respectively will be used to refer to these materials in accordance with [15]). From each material, a plank shaped sample with dimensions $800 \times 140 \times 18$ $\mathrm{mm}^{3}$ is prepared. Apart from the set of test samples, an identical set of reference samples is prepared. Initially, all samples are conditioned at $20^{\circ} \mathrm{C}$ and $65 \% \mathrm{RH}$. Thereafter, the set of reference samples is oven dried to determine the initial moisture content of all materials,

\footnotetext{
${ }^{\mathrm{d}}$ Isoproc Solutions. Celit 3D.

isoproc.be/nl/solutions/producten/detail/celit-3d/355

e Siniat. Duripanel S3(B1).

siniat.be/nl-be/producten-en-

systemen/producten/platen/vezelcementplaat-duripanel
} 
assuming that reference and test samples have the same equilibrium moisture content. With the initial moisture content and mass of the test samples known, an estimation of the oven dry mass of the test samples can be made via Equation (1):

$$
\mathrm{MC}=\left(\mathrm{m}-\mathrm{m}_{\mathrm{o}}\right) / \mathrm{m}_{\mathrm{o}}
$$

with MC (-) the moisture content, $\mathrm{m} \mathrm{(g)} \mathrm{the} \mathrm{mass} \mathrm{of} \mathrm{the}$ sample and $\mathrm{m}_{\mathrm{o}}(\mathrm{g})$ the oven dry mass.

The set of test samples are mounted next to each other in the frame of module A, as shown in Figure 3a for the massive wooden samples and the OSB, and at one side exposed to a constant warm and humid climate of $25^{\circ} \mathrm{C}$ and $97 \% \mathrm{RH}$ created inside module $\mathrm{B}$ of the FCU. In this way, the equilibrium moisture content of the wood species is equal or close to FSP. The goal of this first experiment therefore is to see whether onset of wood decay can occur below FSP, when further in ideal conditions for fungal decay. The duration of this test is one year. Table 1 gives an overview of the first FCU experiment.

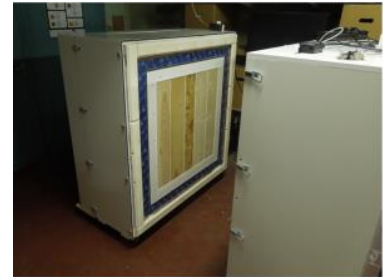

(a)

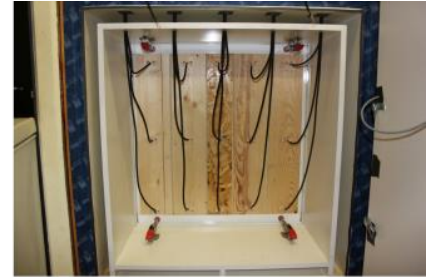

(b)
Figure 3: a) Samples of Scots pine, Norway spruce and OSB are mounted next to each other into the frame of module A; b) The moisture content of the samples is being measured at three heights during the experiment.

Table 1: Overview of FCU test 1

\begin{tabular}{|l|l|}
\hline \multicolumn{2}{|c|}{ FCU test 1 } \\
\hline Materials & - Scots pine (sawn) \\
& - Norway spruce (sawn) \\
& - OSB \\
& - Open WB \\
& - Tight WB \\
\hline Sample dimensions & $800 \times 140 \times 18 \mathrm{~mm}^{3}$ \\
\hline Duration & 1 year \\
\hline Exposure conditions & $25^{\circ} \mathrm{C} \mathrm{\& 97 \% \textrm {RH }}$ \\
\hline
\end{tabular}

\subsection{Moisture content measurements}

In order to follow the moisture content of the samples during the experiment, a pair of needles ${ }^{\mathrm{f}}$, is driven into the back end of each sample at three different heights, as shown in Figure 3b. Conducting wires connect the upper part of the needles with an electrical resistance meter ${ }^{\mathrm{g}}$, with a minimal measuring range from $20 \mathrm{kOhm}$ up to $500 \mathrm{MOhm}$. A relationship between wood moisture

${ }^{\mathrm{f}}$ GANN Electrode needles M-18 Teflon

g Material Moisture Gigamodule \& Materialfox Mini,

Scanntronik Mugrauer $\mathrm{GmbH}$

(http://www.scanntronik.de/Produkt_Materialfox_Varianten_d eu.php) content and electrical resistance has been established by Brischke et al. [16] for Scots pine sapwood and Norway spruce, and by Boardman et al. [17] for OSB. These relationships will be used to determine the moisture content of these materials. For the open and tight WB, the relationship has been determined by Vanpachtenbeke [18]. The reader is referred to Vanpachtenbeke [18] for more details on the moisture content measurements.

The evolution of the electronic measured moisture content (solid lines) of the different samples during FCU test 1 is depicted in Figure 4. Due to a bad contact, results of the middle and bottom measurement of the open WB during the first half of the test are omitted. In addition, the markers indicate the gravimetric determined moisture content of the samples at intermediate and final evaluation moments, based on the estimated oven dry mass as was explained above. The discrepancy between the gravimetric determined initial moisture content and the electronic derived initial moisture content for Scots pine and Norway spruce can be explained by the calibration range of the formula of Brischke et al. [16], which is between $15 \%$ and $50 \%$. Consequently, moisture contents below $15 \%$ are not included in the formula.

Around day 40-50, the samples seem to have reached the equilibrium moisture content. Note though, that in contrast to the gravimetric measurements, the electronic measurements indicate a slight, but gradual increase of the moisture content of the Norway spruce sample during the entire duration of the test. Furthermore, the gravimetric determined moisture content for Scots pine and Norway spruce generally is (significantly) lower than determined via the electrical resistance method. Since the electrical resistance method only measures the moisture content locally, while the gravimetric method gives an average value for entire sample, differences are possible. On the other hand, differences between gravimetric moisture content, which is based on the estimated oven dry mass at the start, and electronic moisture content might indicate the process of fungal decay. This will be investigated in the following subsection. The electronic and gravimetric derived moisture content of the OSB and open WB correspond well, while for the tight WB the gravimetric moisture content indicates lower values. The equilibrium moisture content varies between $24 \%$ and $30 \%$ for Scots pine, and between 26 and $35 \%$ for Norway spruce, depending on the measurement method. Since no liquid water was provided in the test, the moisture content of those samples is expected to be close to, but not exceeding FSP, at least if no fungal decay has established during the experiment. Due to fungal metabolism, the wood moisture content may (locally) increase. The woodbased OSB, open WB and tight WB show a lower equilibrium moisture content around $20 \%$. 


\subsection{Evaluation of wood decay}
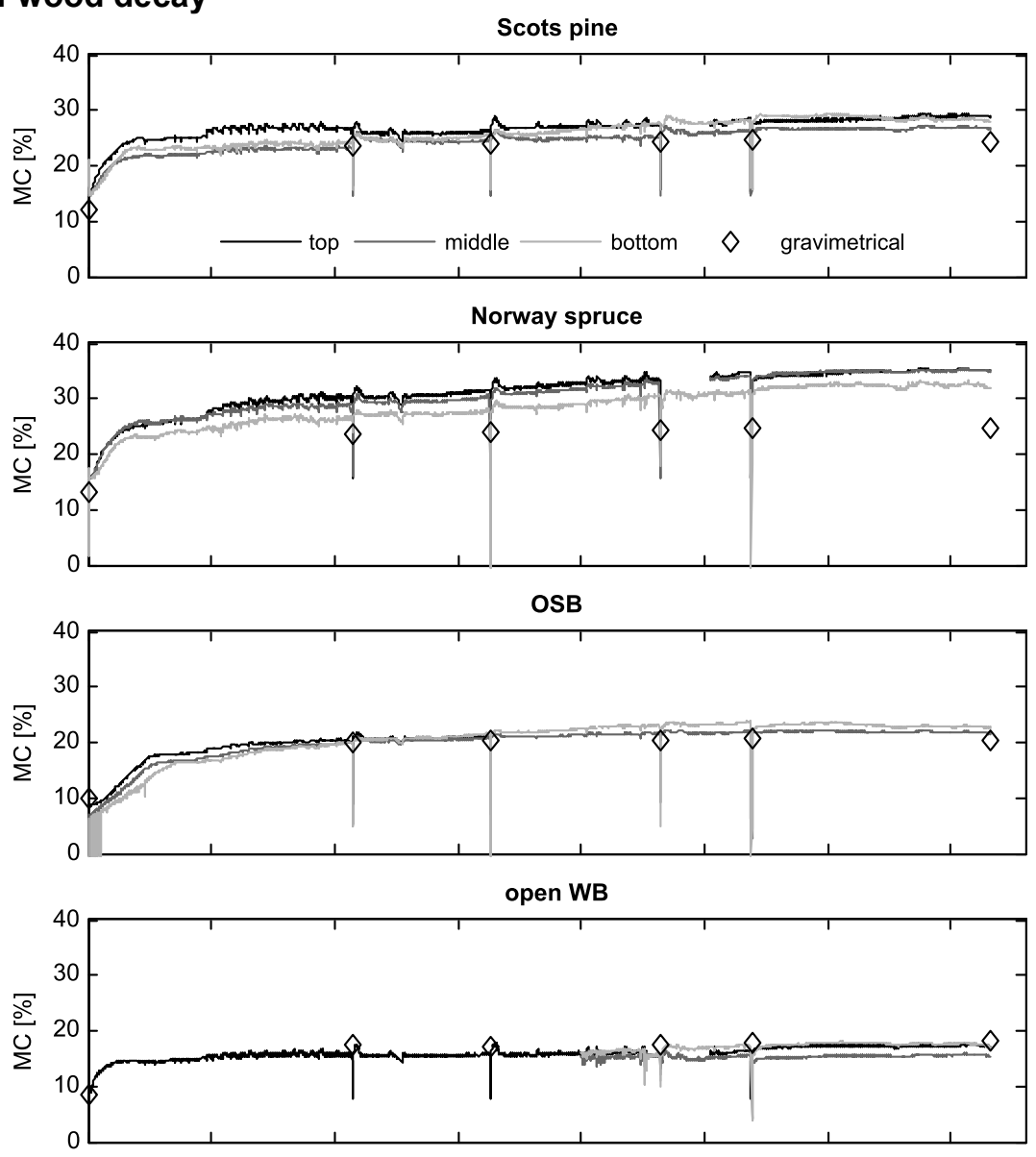

tight WB

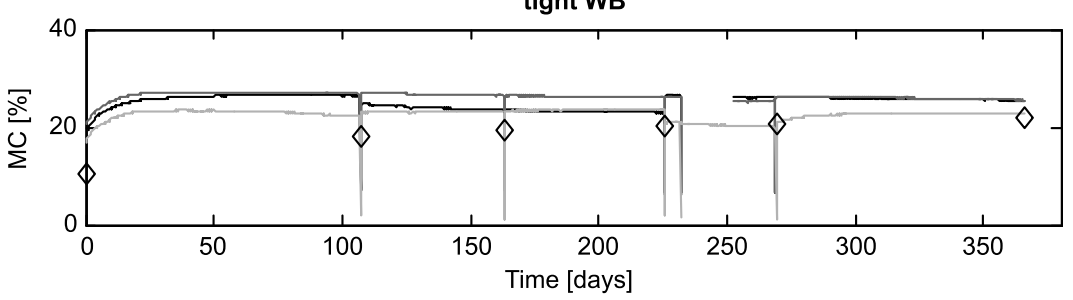

Figure 4: The evolution of the moisture content of the samples in FCU test 1 resulting from the electrical resistance method (solid lines) and from the gravimetric method (markers).

Wood decaying fungi have a (negative) impact on the mass and mechanical properties of the wood. Therefore, next to visual inspection, more objectives parameters like the evolution of mass and stiffness of the wooden samples are used as indicators for the presence of wood decaying fungi. The stiffness of the samples was determined by means of the Resonalyser technique, a non-destructive flexural vibration method [19]. In this test, an accelerometer is glued onto the sample, which is freely suspended on 2 nylon strings. By tapping the sample with a small hammer, the accelerometer registers the time spectrum of the oscillation. The time spectrum is then transformed to the frequency domain in order to determine the eigenfrequency of the resonant mode. The Young's modulus, as a measure of the stiffness of the sample, is then calculated by Equation (2).

$$
E=4 \pi^{2} L^{4} f^{2} \rho A\left(1+I /\left(L^{2} A\right) K_{1}\right) /\left(m_{1}^{4} l\right)
$$

in which $\mathrm{L}(\mathrm{mm})$ is the length of the sample, $\mathrm{f}(\mathrm{kHz})$ the eigenfrequency, $\rho\left(\mathrm{kg} / \mathrm{m}^{3}\right)$ the density, $A\left(\mathrm{~mm}^{2}\right)$ the cross-section area and $\mathrm{I}\left(\mathrm{mm}^{4}\right)$ the moment of inertia. $\mathrm{m}_{1}$ and $K_{1}$ are constants equal to 4.72 and 49.48 respectively. Note, though, that wood moisture content has a strong impact on both the mass and the stiffness of wood. Based on measurements on Scots pine carried out by Machek et al. [20] and Krause et al. [21], the decrease in modulus of elasticity is around $20-25 \%$ when a sample with initial moisture content of $10 \%$ reaches fibre saturation point. Beyond the fibre saturation point, the modulus of elasticity is hardly influenced by the moisture content.

Since the stiffness strongly depends on the moisture content of the samples, the evolution of mass and stiffness is compared to the equilibrium as reference point: if no wood decaying fungi are active in the samples, the mass and stiffness should stay constant as soon as equilibrium has been reached. Figure 5 presents 
the evolution of the mass of the samples during the experiment relative to the first measuring point after 107 days when equilibrium is assumed to be reached. After equilibrium has been reached, the mass change stays within a $+/-1 \%$ range, except for the tight WB. Given its high moisture buffer capacity, the tight WB most likely is not yet in equilibrium with the environment.

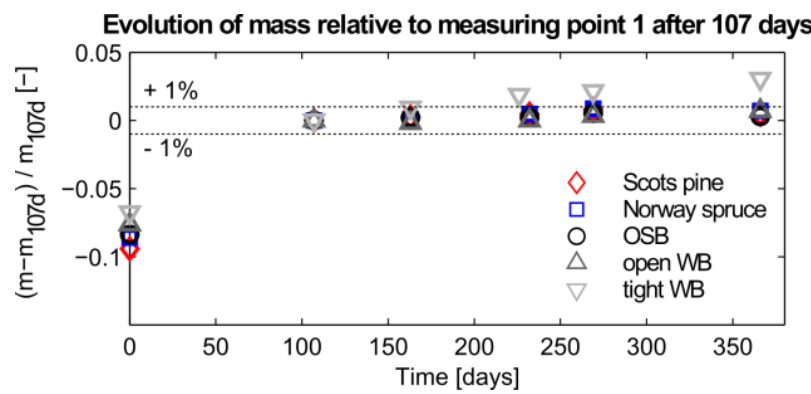

Figure 5: Evolution of the mass of the samples during FCU test 1 .

In addition, Table 2 presents the estimated oven dry mass assuming no decay has been established, and the measured final oven dry mass after the experiment. Except for the tight $\mathrm{WB}$, the difference is indeed approximately within a $+/-1 \%$ margin.

Table 2: Comparison of the measured oven dry mass after one year of exposure and the estimated oven dry mass assuming no mass loss.

\begin{tabular}{|l|l|l|}
\hline $\begin{array}{l}\text { Oven dry mass }(g) \\
\text { after one year of } \\
\text { exposure }\end{array}$ & $\begin{array}{l}\text { Estimated in case of no } \\
\text { mass loss (1\% error } \\
\left.\text { margin on } m_{0}\right)\end{array}$ & Measured \\
\hline Scots pine & $998(988-1008)$ & 1000 \\
\hline Norway spruce & $1017(1007-1027)$ & 1028 \\
\hline OSB & $1118(1106-1129)$ & 1108 \\
\hline Open WB & $480(475-485)$ & 482 \\
\hline Tight WB & $2347(2323-2370)$ & 2486 \\
\hline
\end{tabular}

Further, Figure 6 presents the evolution of the stiffness of the samples relative to the first measuring point after 107 days. For scots pine, however, the relative value is based on the measurement after 232 days, since the previous two measurements gave unreliable results. Further, also unreliable results were obtained for both the open and tight WB, and are therefore omitted in Figure 6. Compared to the initial state, the E-modulus drops by approximately $10 \%$ for Scots pine and Norway spruce and by $40 \%$ for OSB after equilibrium moisture content has been reached. Thereafter, the stiffness of the samples remains quasi constant. Relative to the first measuring point after equilibrium, changes are within a $+/-3 \%$ range. A final evaluation of the samples in equilibrium with $20^{\circ} \mathrm{C}$ and $65 \%$ RH shows that for Scots pine and Norway spruce, the difference between initial and final stiffness is within a 2\% margin (Table 3). A significant difference is obtained between initial and final stiffness of the OSB sample, caused by a permanent dimensional deformation $(+2 \mathrm{~mm}$ in thickness) rather than fungal activity.

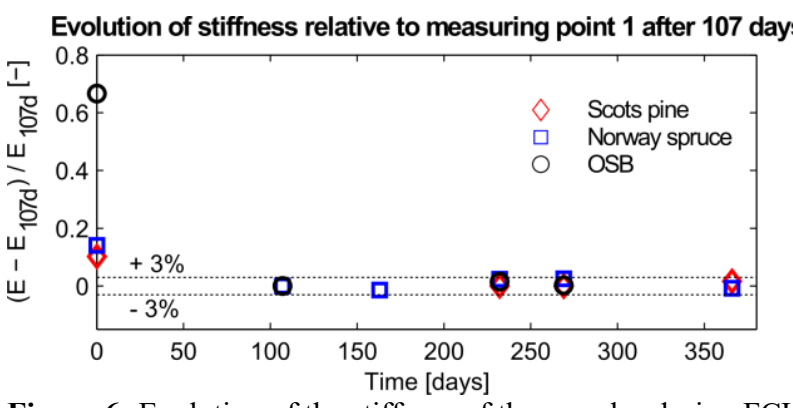

Figure 6: Evolution of the stiffness of the samples during FCU test 1

Table 3: Comparison of the initial and final stiffness at $20^{\circ} \mathrm{C}$ and $65 \%$ RH for the samples of FCU test 1.

\begin{tabular}{|c|c|c|c|}
\hline $\begin{array}{l}\text { Stiffness }\left(\mathrm{N} / \mathrm{mm}^{2}\right) \text { at } \\
20^{\circ} \mathrm{C} \text { and } 65 \% \mathrm{RH}\end{array}$ & Initial & Final & $\begin{array}{l}\text { Difference } \\
(\%)\end{array}$ \\
\hline Scots pine & 13610 & 13446 & 1.2 \\
\hline Norway spruce & 16816 & 16538 & 1.6 \\
\hline OSB & 6731 & 4477 & 33 \\
\hline
\end{tabular}

\section{FCU - test 2}

In a second FCU test, the onset of wood decay in case a liquid water source is available is investigated. Therefore, two small-scale timber frame inner walls are installed next to each other in module A of the FCU (Figure 7). The wooden frame of both walls is made from Norway spruce, and the voids are filled with mineral wool insulation. One wall is provided with the more vapour open 'open WB' as exterior sheathing, the other one with the more vapour tight 'tight WB'. OSB again serves as interior sheathing. In order to create a liquid water source inside the constructions, interstitial condensation is induced. Therefore, as depicted in Figure 7, module $\mathrm{C}$ of the FCU is extended with a cooling unit and a humidifier. The climate conditions in module $\mathrm{C}$ are controlled at $5^{\circ} \mathrm{C}\left(+/-0.3^{\circ} \mathrm{C}\right)$ and $80 \% \mathrm{RH}(+/-4 \% \mathrm{RH})$, whereas in module $\mathrm{B}$ a constant warm and humid climate of $25^{\circ} \mathrm{C}$ and $60 \% \mathrm{RH}$ is maintained. In addition, three holes of approximately $350 \times 200 \mathrm{~mm}^{2}$ were cut out of the OSB at three heights, to enhance condensation conditions. According to an elementary Glaser calculation (CEN 2001), these conditions will lead to interstitial condensation at the interface between mineral wool and wind barrier for both set-ups. The condensation flux for the vapour tight set-up, however, is two orders of magnitude higher. Finally, in FCU test 1, only loose samples were considered. However, apart from exposure conditions, also design details might play a crucial role in the development of wood-rotting fungi. Therefore, in FCU test 2, next to the two test walls in which interstitial condensation is induced, also two reference walls identical to these test walls are considered, yet without providing a liquid water source. The reference walls are exposed to a constant warm and humid climate of $25^{\circ} \mathrm{C}$ and $97 \% \mathrm{RH}$, similar as in FCU test 1 . Table 4 gives an overview of the tests executed in the second FCU experiment. 


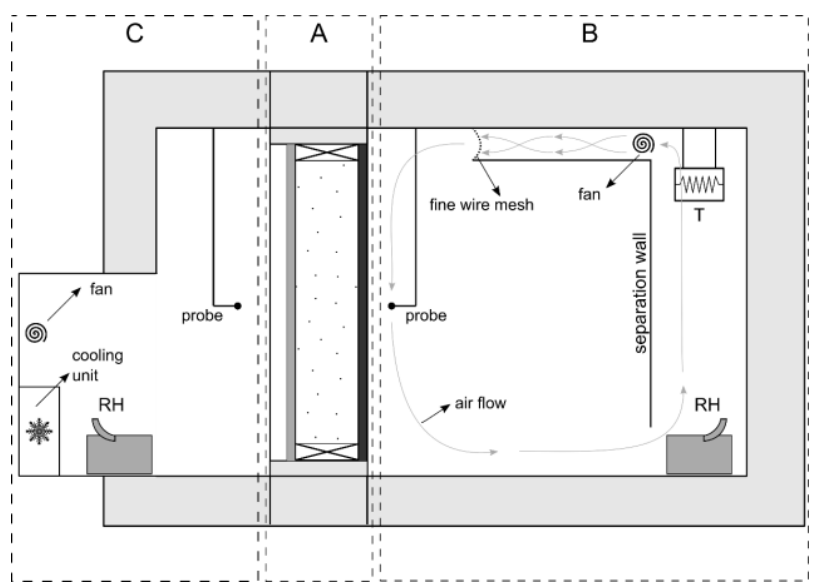

Figure 7: Schematic overview of the FCU with an extended version of module $\mathrm{C}$.

Table 4: Overview of FCU test 2

\begin{tabular}{|c|c|c|}
\hline \multicolumn{3}{|c|}{ FCU test 2} \\
\hline & Test wall & Reference wall \\
\hline Materials & $\begin{array}{l}\text { Wall 1: } \\
\text { - OSB (warm side) } \\
\text { - MW + Norway } \\
\text { spruce } \\
\text { - open WB (cold } \\
\text { side) } \\
\text { Wall 2: } \\
\text { - OSB (warm side) } \\
\text { - MW + Norway } \\
\text { spruce } \\
\text { - tight WB (cold } \\
\text { side) }\end{array}$ & $\begin{array}{l}\text { Wall 1: } \\
\text { - OSB } \\
\text { - MW + Norway } \\
\text { spruce } \\
\text { - open WB } \\
\text { Wall 2: } \\
\text { - OSB } \\
\text { - MW + Norway } \\
\text { spruce } \\
\text { - tight WB }\end{array}$ \\
\hline Dimensions & $930 \times 420 \times 220 \mathrm{~mm}^{3}$ & $930 \times 420 \times 220 \mathrm{~mm}^{3}$ \\
\hline Duration & $+/-9$ months & $+/-9$ months \\
\hline $\begin{array}{l}\text { Exposure } \\
\text { conditions }\end{array}$ & $\begin{array}{l}\text { warm climate: } 25^{\circ} \mathrm{C} \\
\& 65 \% \mathrm{RH} \\
\text { cold climate: } \\
+/-5^{\circ} \mathrm{C} \& 80 \% \mathrm{RH}\end{array}$ & $25^{\circ} \mathrm{C} \& 97 \% \mathrm{RH}$ \\
\hline $\begin{array}{l}\text { Liquid } \\
\text { water } \\
\text { source }\end{array}$ & $\begin{array}{c}\text { Interstitial } \\
\text { condensation }\end{array}$ & $\begin{array}{c}\text { No liquid water } \\
\text { source }\end{array}$ \\
\hline
\end{tabular}

\subsection{Moisture content measurements}

At specific locations inside the construction of the test walls, the moisture content has been measured via the electrical resistance method. Moisture pins are provided at the top, middle and bottom of the wooden frame, OSB and wind barrier. All moisture pins in the wooden frame are drilled $2 \mathrm{~cm}$ deep into the wood. For the wooden frame in the vapour open test wall, the moisture content stayed below FSP during the entire experiment. Hence, the climate conditions were not severe enough to induce a significant amount of condensation in this set-up. In contrast, condensation clearly took place inside the test wall provided with the vapour tight WB. This resulted, however, only in an elevated moisture content at the lower parts of the construction due to run-off, as shown in Figure 8. The moisture content of the bottom part of the wooden frame is above FSP, whereas the upper part is below FSP.

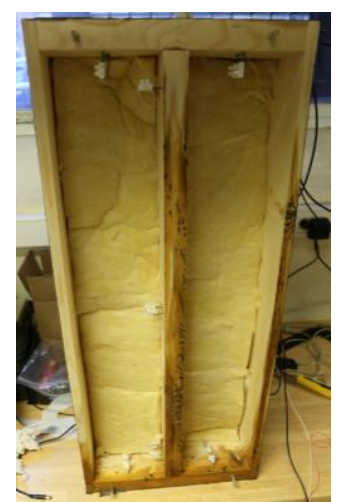

Figure 8: Due to condensation run-off, the lower part of the wooden frame has a moisture content above FSP.

\subsection{Evaluation of wood decay}

The evaluation of wood decay in FCU test 2 is only performed at the end of the experiment, by comparing the final mass and stiffness of the wooden samples in equilibrium with $20^{\circ} \mathrm{C}$ and $65 \% \mathrm{RH}$. Also, the estimated oven dry mass, based on an initial moisture content between $10 \%$ and $12 \%$ at $20^{\circ} \mathrm{C}$ and $65 \% \mathrm{RH}$, is compared to the final oven dry mass. Table 5 and Table 6 summarize the results for the test walls and reference walls respectively. Although no significant deviations from the initial situation are observed, the bottom plate and the right column of the tight WB test wall show a slightly higher decrease in stiffness. Moreover, the final oven dry mass of this bottom plate is also slightly lower as estimated. Nevertheless, no clear signs of wood decay were observed visually.

\section{Discussion}

The previous sections discussed the outcomes of different experiments regarding the onset and progress of wood decay on construction wood and/or wood-based materials. In a first test, FCU test 1 , the onset of fungal decay when no liquid water source is available was investigated. Therefore, plank shaped samples of wood and wood-based materials were exposed to a constant warm and humid climate of $25^{\circ} \mathrm{C}$ and $97 \% \mathrm{RH}$. In this way the moisture content of the wood was equal or close to FSP yet without exceeding it. After a total exposure time of one year, no signs of wood decay were observed for all samples. This is generally in line with experiments in literature which do not include a liquid water source and in which the MC is below FSP $[12,13]$. This might indicate that onset of decay cannot happen if there is no liquid water source available and if the moisture content of the wood is below FSP. In contrast, however, according to the experiments of Viitanen [11] and the corresponding decay model of Viitanen et al. [22], significant mass loss $(>10 \%)$ for Scots pine and Norway spruce exposed to $97 \% \mathrm{RH}$ and $25^{\circ} \mathrm{C}$ should be expected, even when only the period in which the 
Table 5: Comparison of the estimated and final oven dry mass, and the initial and final stiffness of the wooden plates and columns of the test walls in FCU test 2.

\begin{tabular}{|c|c|c|c|c|c|}
\hline \multirow{2}{*}{\multicolumn{2}{|c|}{ Test walls }} & \multicolumn{2}{|c|}{ Oven dry mass (g) } & \multicolumn{2}{|c|}{ Stiffness $\left(\mathbf{N} / \mathbf{m m}^{2}\right)$} \\
\hline & & estimated & final & initial & final \\
\hline \multirow{5}{*}{ Open WB wall } & Top plate & $913-929$ & 916 & 10813 & $10698(-1.1 \%)$ \\
\hline & Bottom plate & $937-954$ & 935 & $-*$ & $-*$ \\
\hline & Left column & $1158-1179$ & 1163 & $-*$ & $11697(-)$ \\
\hline & Middle column & $2122-2161$ & 2141 & $-*$ & $11638(-)$ \\
\hline & Right column & $1135-1155$ & 1140 & $-*$ & $10423(-)$ \\
\hline \multirow{5}{*}{ Tight WB wall } & Top plate & $964-981$ & 966 & 7261 & $7264(-0.0 \%)$ \\
\hline & Bottom plate & $937-954$ & 930 & 10261 & $9886(-3.7 \%)$ \\
\hline & Left column & $1167-1188$ & 1173 & 10952 & $10962(+0.1 \%)$ \\
\hline & Middle column & $2143-2182$ & 2158 & 11669 & $11540(-1.1 \%)$ \\
\hline & Right column & $1131-1152$ & 1138 & 11925 & $11512(-3.5 \%)$ \\
\hline
\end{tabular}

Table 6: Comparison of the estimated and final oven dry mass, and the initial and final stiffness of the wooden plates and columns of the reference walls in FCU test 2.

\begin{tabular}{|c|c|c|c|c|c|}
\hline \multirow{2}{*}{\multicolumn{2}{|c|}{ Reference walls }} & \multicolumn{2}{|c|}{ Oven dry mass (g) } & \multicolumn{2}{|c|}{ Stiffness $\left(\mathrm{N} / \mathbf{m m}^{2}\right)$} \\
\hline & & estimated & final & initial & final \\
\hline \multirow{5}{*}{ Open WB wall } & Top plate & $963-981$ & 971 & 5538 & $5393(-2.6 \%)$ \\
\hline & Bottom plate & $969-987$ & 969 & 8478 & $8307(-2 \%)$ \\
\hline & Left column & $1212-1234$ & 1222 & 13428 & $13400(-0.2 \%)$ \\
\hline & Middle column & $2076-2114$ & 2086 & 10405 & $10346(-0.6 \%)$ \\
\hline & Right column & $1212-1234$ & 1224 & 13587 & $13485(-0.8 \%)$ \\
\hline \multirow{5}{*}{ Tight WB wall } & Top plate & $918-935$ & 920 & 10819 & $10799(-0.2 \%)$ \\
\hline & Bottom plate & $947-965$ & 950 & 9243 & $9167(-0.8 \%)$ \\
\hline & Left column & $1213-1235$ & 1223 & 12934 & $13077(+1.1 \%)$ \\
\hline & Middle column & $2272-2314$ & 2314 & 13094 & $13036(-0.4 \%)$ \\
\hline & Right column & $1170-1191$ & 1181 & 12052 & $11937(-1.0 \%)$ \\
\hline
\end{tabular}

samples are already in equilibrium with the imposed conditions is considered. Although the wood decay model of Viitanen et al. [22] is applied in combination with hygrothermal simulations, e.g. [23], and is implemented in some HAM-simulation software packages as post-processing damage tool for wooden components, e.g. DELPHIN [24], it is important to keep in mind that this model is based on static laboratory tests including inoculation and hence might be highly conservative.

In a second FCU test, a small-scale timber frame wall is considered, in which interstitial condensation is induced. Based on the measurement data, it cannot be confirmed whether onset of wood decay has established within the wood. Loss of mass and stiffness was still limited after an exposure time of $+/-9$ months. The lack of inoculum in these tests lead to different results than laboratory tests with a liquid water source in which the samples are inoculated (a.o. $[9,10])$. Consequently, there might be a significant time delay between the onset and progress of wood decay.

Finally, some limitations of the tests conducted in this chapter should be discussed. First, the FCU tests were conducted without controlling the fungal spore pressure as a parameter. Tests were conducted in a normal indoor environment. Consequently, other results might be obtained if these tests would be executed in a different environment. Secondly, due to time restrictions in this work, it should be stressed that all FCU tests had a maximal exposure time of one year. Although these tests give a good idea how fast and severe wood decay can occur in the considered exposure conditions, tests over several years should be conducted to confirm the conclusions in this work. Finally, steady-state conditions were considered in FCU test 2, including a constant cold and warm climate. Interstitial condensation inside the timber frame inner wall occurred at the cold surface of the wall. In this way, elevated moisture contents were mostly situated at the cold side, which makes it less favourable for fungal growth. Therefore, it would be interesting to impose dynamic conditions at this surface, alternating between a warm and cold climate. The ability of the wet timber to fully dry out will be crucial here whether fungal decay is able to develop.

\section{Conclusion}

The present paper discussed the outcomes of different experiments regarding the onset and progress of wood decay on construction wood and/or wood-based materials. Based on a literature survey, conducted experiments reported in literature lead to contradictory conclusions on the minimal moisture threshold for fungal decay. These experiment, however, are all very different in set-up and, moreover, benefitted from inoculation and sterile conditions. The aim of this paper is to study the onset and progress of wood decay timber frame walls in more realistic conditions, where fungal spores first need to settle onto the wood before germination and growth can occur. Therefore, a newly developed test unit has been elaborated at UGentWoodlab. Experiments with this test unit were classified whether there was a liquid water source available. A liquid water source might be crucial for fungi to survive 
and grow. In a first test, FCU test 1, the onset of fungal decay when no liquid water source is available was investigated. In this test, the moisture content of the wood was equal or close to FSP yet without exceeding it. After a total exposure time of one year, no signs of wood decay were observed. This is in line with the assumption in literature that onset of wood decay is not possible below FSP without a liquid water source nearby. In a second test, a small-scale timber frame wall was considered, in which interstitial condensation was induced. Based on the measurement data after 9 months of exposure, it cannot be confirmed whether onset of wood decay has already established within the wood. Compared to experiments in literature, however, this might indicate a significant time delay between onset and progress of wood decay. These tests showed that the newly developed test unit is a good tool to study wood decay in timber frame walls in more realistic conditions. However, these tests should be repeated for a longer time period to confirm these preliminary results.

The research presented in this paper is part of research project 3E140592 funded by the Fonds voor Wetenschappelijk Onderzoek - Vlaanderen (FWO): 'A stochastic and dynamic risk assessment methodology for mould growth and wood rot on timber frame constructions.'

\section{References}

1. Vlaams Instituut voor Bio-Ecologisch Bouwen \& Wonen, Hout zonder chemische verduurzaming, 2007.

2. S. Winter, Wood Is Good ?! - Worldwide Threats and Consequent Opportunities for Building with Wood, in: Proc. WCTE 2016 World Conf. Timber Eng. Vienna / Austria, August 22-25, 2016, 2016: pp. 37-45.

3. New Zealand Parliament, Leaky buildings, 2002.

4. G. Finch, B. Hubbs, Peng, M.J. Dell, Rainscreen walls: Long-Term Performance and Field Monitoring in Coastal British Columbia, in: Symp. Build. Envel. Technol., 2008.

5. N. Hurel, Impact of air infiltration on buildings' performance: focus on the experimental study within timber frame walls, Université Grenoble Alpes, 2006.

6. J. Langmans, Feasibility of Exterior Air Barriers in Timber Frame Constructions, KU Leuven, Belgium. PhD thesis., 2013.

7. S.D. Platt, C.J. Martin, S.M. Hunt, C.W. Lewis, Damp housing, mould growth, and symptomatic health state., BMJ. 298 (1989) 1673-8.

https://doi.org/10.1136/bmj.298.6689.1673.

8. IEA-Annex 14, Condensation and energy. Guidelines \& Practice, Acco, Leuven, 1990

9. T. Stienen, O. Schmidt, T. Huckfeldt, Wood decay by indoor basidiomycetes at different moisture and temperature, Holzforschung. 68 (2014) 9-15. https://doi.org/10.1515/hf-2013-0065.

10. L. Meyer, C. Brischke, Fungal decay at different moisture levels of selected European-grown wood species, Int. Biodeterior. Biodegrad. 103 (2015) 23 29. https://doi.org/10.1016/j.ibiod.2015.04.009.

11. H. Viitanen, Modelling the Time Factor in the Development of Brown Rot Decay in Pine and Spruce Sapwood - The Effect of Critical Humidity and Temperature Conditions, Holzforschung. 51 (1997) 99-106.
12. H. Saito, K. Fukuda, T. Sawachi, Integration model of hygrothermal analysis with decay process for durability assessment of building envelopes, Build. Simul. 5 (2012) 315-324.

https://doi.org/10.1007/s12273-012-0081-8.

13. C. Brischke, A. Soetbeer, L. Meyer-Veltrup, The minimum moisture threshold for wood decay by basidiomycetes revisited. A review and modified pile experiments with Norway spruce and European beech decayed by Coniophora puteana and Trametes versicolor, Holzforschung. 71 (2017) 893-903. https://doi.org/10.1515/hf-2017-0051.

14. J. Van den Bulcke, J. Van Acker, M. Stevens, Laboratory testing and computer simulation of blue stain growth on and in wood coatings, Int. Biodeterior. Biodegrad. 59 (2007) 137-147.

https://doi.org/10.1016/j.ibiod.2006.08.009.

15. M. Vanpachtenbeke, J. Van Den Bulcke, J. Van Acker, S. Roels, Hygrothermal performance of timber frame walls with brick veneer cladding: a parameter analysis, in: Proc. 12th Symp. Build. Phys. NSB 2020, Tallinn, Estonia, 2020.

16. C. Brischke, A.O. Rapp, R. Bayerbach, Measurement system for long-term recording of wood moisture content with internal conductively glued electrodes, Build. Environ. 43 (2008) 1566-1574. https://doi.org/10.1016/j.buildenv.2007.10.002.

17. C.R. Boardman, S. V Glass, P.K. Lebow, Simple and accurate temperature correction for moisture pin calibrations in oriented strand board, Build. Environ. 112 (2017) 250-260. https://doi.org/10.1016/j.buildenv.2016.11.039.

18. M. Vanpachtenbeke, Timber frame walls with brick veneer cladding: reliability to fungal decay, $\mathrm{KU}$ Leuven, Belgium. PhD thesis., 2019.

19. W. Li, J. Van den Bulcke, I. De Windt, N. Defoirdt, J. Dhaene, M. Dierick, H. Sol, J. Van Acker, Relating MOE decrease and mass loss due to fungal decay in plywood and MDF using resonalyser and X-ray CT scanning, Int. Biodeterior. Biodegradation. 110 (2016) 113-120. https://doi.org/10.1016/j.ibiod.2016.03.012.

20. L. Machek, H. Militz, R. Sierra-Alvarez, The influence of wood moisture content on dynamic modulus of elasticity measurements in durability testing, Holzforsch. Und Holzverwertung. 53 (2001) 97-100.

21. A. Krause, A. Pfeffer, H. Militz, The use of nondestructive methods for the evaluation of fungal decay in field testing by dynamic vibration, in: Futur. Qual. Control Wood Wood Prod., 2010: pp. 4-7.

22. H. Viitanen, T. Toratti, L. Makkonen, R. Peuhkuri, T. Ojanen, L. Ruokolainen, J. Räisänen, Towards modelling of decay risk of wooden materials, Eur. J. Wood Wood Prod. 68 (2010) 303-313. https://doi.org/10.1007/s00107-010-0450-x.

23. M. Guizzardi, J. Carmeliet, D. Derome, Risk analysis of biodeterioration of wooden beams embedded in internally insulated masonry walls, Constr. Build. Mater. 99 (2015) 159-168. https://doi.org/10.1016/j.conbuildmat.2015.08.022.

24. A. Nicolai, Modeling and Numerical Simulation of Salt Transport and Phase Transitions in Unsaturated Porous Building Materials, Syracuse University, USA. PhD thesis., 2007. 